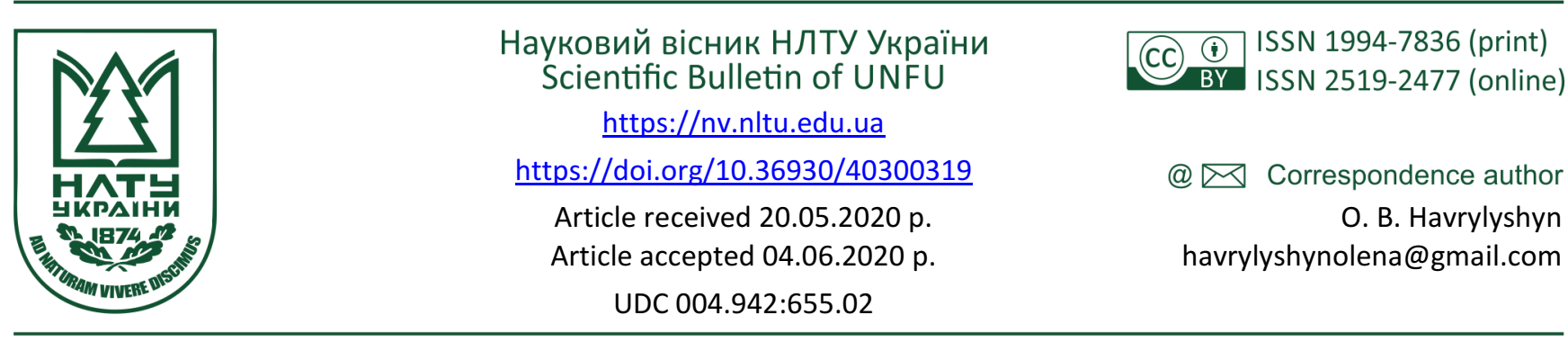

О. Б. Гаврилишин, В. Б. Репета, І. З. Миклушка

Українська академія друкарства, м. Львів, Украӥна

\title{
АНАЛІЗ ПРОЦЕСУ ОЦИФРОВУВАННЯ СТАРОДРУКІВ
}

Проаналізовано особливості процесу оцифровування стародрукованих книжкових видань, як одного із сучасних методів зберігання української та світової культурної спадщини. Встановлено основні вади і дефекти паперової основи стародруків та нанесеного на неї зображення, їх вплив на показники отриманої цифрової копії та варіанти їх усунення, як на рівні спеціалізованого обладнання, так і на рівні програмного забезпечення. Розглянуто етапи перетворення стародрукованих книжкових видань в електронну форму та варіанти збереження цифрової копії з різною роздільною здатністю і рівнем стискання залежно від призначення. Виокремлено основні фактори, врахування особливостей яких уможливлює забезпечення якості процесу оцифровування стародруків: стан стародруку, оптичний діапазон зображення на сторінці стародруку, особливість сканувального обладнання, розподіл освітлення під час оцифровування, функціональність програмного забезпечення, рівень цифрового шуму, характеристика цифрової копії. Встановлено особливості обладнання для сканування стародрукованих книжкових видань, а саме: наявність V-подібного тримача, щоб запобігти руйнуванню сканованого раритету; роздільна здатність реєструвальної системи не менше 600 pрі, що уможливлює високоякісне поліграфічне відтворення; кольорова температура джерела світла 6000 К, щоб запобігти кольоровим спотворенням оригіналу у процесі оцифровування. На основі аналізу розроблено загальну структурну модель процесу оцифровування стародруків, яка охоплює підготовчі операції, що передують оцифровуванню стародруку, операцію отримання цифрової мастер-копії і цифрове оброблення копій залежно від мети застосування, зокрема оброблення для видавничо-поліграфічного відтворення.

Ключові слова: стародруковане видання; процес оцифровування; дефекти оригіналу; фактори якості; формати збереження; структурна модель.

\section{Вступ}

Збереження друкованої культурної спадщини, формування знань і створення інформаційного середовища сьогодні, як на нашу думку, має бути пріоритетним завданням держави і суспільства. Вирішення цієї проблеми нерозривно пов'язане з розвитком видавничої, бібліотечної та архівної справи. 3 огляду на це потрібно затвердити державні програми і реалізувати IT-проекти, що покликані забезпечити доступність наукової, науково-популярної та освітньої літератури широкому колу читачів.

У "доцифровій" ері людство накопичувало величезні обсяги паперових документів, видань, які сьогодні зберігаються у бібліотеках і архівах, оснащених далеко не найкращою технікою і працівниками, які поверхнево володіють цією технікою. 3 розвитком інформаційних технологій повстало питання збереження таких документів у цифровому вигляді та ознайомлення 3 ними зацікавлених осіб, застосовуючи при цьому різні засоби візуалізації. Для кожного випадку, за потреби отримання якісної цифрової копії старовинного документу, ви- никає завдання ефективного виконання технологічного процесу оцифровування, який через різноманіття стародруків не підлягає стандартизованій параметризації. Необхідні нові рішення та шляхи вирішення проблеми для забезпечення та прогнозування процесу оцифровування стародруків як на окремих операціях, так і загалом, з виявленням впливу різних факторів процесу, що робить цю роботу актуальною.

Об'єктом дослідження є процес оцифровування стародрукованих видань.

Предметом дослідження є методи і засоби, які дають змогу визначити фактори впливу на процес оцифровування стародрукованих видань, а також побудувати відповідні моделі технології оцифровування.

Мета роботи - проаналізувати технологічний процес оцифровування стародрукованих видань, виявити його особливості та низку факторів, врахування яких дає змогу отримати якісну цифрову копію.

Завдання дослідження: проаналізувати та встановити особливості технологічного процесу оцифровування стародруків; визначити недоліки процесу оцифровування та відповідні дефекти на цифровій копії; виявити

Інформація про авторів:

Гаврилишин Олена Богданівна, асистент, кафедра інформаційних мультимедійних технологій.

Email: havrylyshynolena@gmail.com; https://orcid.org/0000-0001-7181-4421

Репета Вячеслав Богданович, д-р техн. наук, доцент, кафедра поліграфічного матеріалознавства і хімії. Email: vreneta@gmail.com; https://orcid.org/0000-0003-3204-1512

Миклушка Ігор Зіновійович, канд. техн. наук, доцент, кафедра інформаційних мультимедійних технологій. Email: myklushka@gmail.com; https://orcid.org/0000-0003-3794-020X

Цитування за ДСту: Гаврилишин О. Б., Репета В. Б., Миклушка І. З. Аналіз процесу оцифровування стародруків. Науковий вісник НЛТУ України. 2020, т. 30, № 3. С. 106-110.

Citation APA: Havrylyshyn, O. B., Repeta, V. B., \& Myklushka, I. Z. (2020). The analysis of the process of old books digitalization. Scientific Bulletin of UNFU, 30(3), 106-110. https://doi.org/10.36930/40300319 
фактори, які визначають якість перебігу процесу оцифровування та, відповідно, отриманої цифрової копії.

Наукова новизна результатів дослідження полягає у тому, що встановлено основні фактори, які визначають якість процесу оцифровування стародруків, що уможливить їх дослідження методами теорії ієрархій та побудову моделі прогнозування якості оцифровування засобами нечіткої логіки.

Практична значущість результатів дослідження полягає у виявленні особливостей сучасного процесу оцифровування стародруків та формуванні структурної моделі процесу оцифровування стародруків, яка висвітлює підготовчі операції, що передують оцифровуванню стародруку, операцію отримання цифрової мастер-копії і цифрове оброблення копій зі зазначенням характеристик зображень залежно від мети застосування.

Аналіз літературних джерел. Згідно з виконаним аналізом аналітичною компанією Maximize Market Research, для світового ринку реєстрації документів за період 2019-2027 рр. прогнозують зростання на $14 \%$ [4], що свідчить про зростаючі тенденції й у частці оцифровування стародрукованих видань. Актуальність завдань та проблематику оцифровування стародруків, які повстають перед бібліотеками, висвітлено у роботі $[1,5]$. Інший напрям публікацій стосується підходів в організації та каталогізації повнотекстових баз даних книжкових пам'яток - рідкісних і цінних видань, пошуку та доступу до них $[10,11]$. Низка робіт присвячена аналізу чи розробленню методів цифрової оброблення для усунення дефектів архівних документів [9, 8, 15, 16]. Публікацій з виявленням факторів, які в комплексі визначають якість процесу оцифровування стародруків, немає.

\section{Викладення основного матеріалу}

Зазвичай в Україні та інших сусідніх країнах стародруками прийнято називати книги, що надруковані до 1830 р. [18]. Зокрема, до рідкісних книг належать видання, що мають певну суспільну, естетичну, наукову чи іншу цінність і які збережені у відносно малій кількості примірників. Зрозуміло, що фізичний доступ до таких видань $є$ значно ускладнений як для науковців, так і охочих до пізнання, тому потребує виконання відповідних процедур і правил поводження 3 рідкісними архівними документами. Враховуючи сучасні технічні можливості оцифровування паперових носіїв інформації і те, що кожен користувач, маючи персональний комп'ютер, смартфон чи планшет та відповідне програмне забезпечення, може у будь-який момент часу ознайомитися зі змістом таких видань через мережу Інтернет, більшість бібліотек України, які зберігають стародруки, намагаються виконати їх оцифровування.

Сьогодні існують методи безконтактного сканування важливих документів, що дає змогу застосувати їх і для сканування стародруків, не пошкоджуючи їхню цілісну структуру [18]. Після процесу сканування растрові зображення перетворюють в електронну форму, формат електронної книжки, який забезпечує миттєвий доступ до них у будь-якому куточку світу. Однак процес сканування важливих документів потребує виконання двох обов'язкових вимог, а саме:

- забезпечення цілісності документа у процесі сканування;

- можливість оперативного доступу до електронного документа, який $є$ автентичним щодо його оригіналу.

Для того, щоб якомога якісніше здійснити процес оцифровування стародруків, насамперед потрібно виз- начити основні їхні дефекти та недоліки, які можна усунути ще до процесу сканування. Отже, роботу над перетворенням стародруків в електронне видання можна поділити на три етапи:

1. Опрацювання оригінального матеріалу стародруку 3 урахуванням того, що цей процес не зашкодить йому і не призведе до втрати його автентичності та виконання реставраційних робіт за потреби;

2. Оцифровування стародруку та збереження мастер-копії;

3. Опрацювання оцифрованого матеріалу у відповідних програмних додатках, збереження копій документа 3 відповідними характеристиками та їх використання залежно від потреби.

Процеси оцифровування нерозривно пов'язані з попередньою підготовкою оригіналів. Інколи достатньо просто виконати очищення поверхонь від зайвих дефектів, підготувати обладнання і створити відповідні умови. Але в деяких випадках фаховим спеціалістам-реставраторам потрібно виконати роботи 3 відновлення оригіналу.

Якщо розглядати перший етап, то неважко виділити певні обмеження щодо процесу реставрації, пов'язані $з$ історією виникнення, проблемами зберігання та хронологію функціонування стародруків. Наприклад, якщо готувати до оцифровування такі архівні реліквії, як ікони, то $є$ певні застереження щодо самого процесу їхньої реставрації, адже впродовж свого хронологічного життя вони накопичували історико-культурний період різних поколінь, переживали зміну законів, виявляли факти людських зцілень тощо. Для того, щоб проаналізувати цю історичну властивість старовинних ікон, не треба заглиблюватись у період іконоборства, достатньо згадати часи початку минулого століття, де державну політику провадили на винищення усього старого, релігійного, що суперечило тодішній ідеології. Отже, важливою ознакою реставраційних робіт $є$ ознайомлення 3 оригіналом і надання йому первісного вигляду, враховуючи весь історичний пласт, що супроводжував його в період від створення і до процесу оцифровування.

Розглянемо докладніше дефекти, характерні для архівних стародруків. Стародрук - це система, що складається 3 носія інформації (папір) і засобів фіксації інформації - друкарська фарба, чорнило, різноманітні відмітки, маргіналії, позначки тощо. Тому дефекти стародруків можна розділити на дві основні групи:

1. Дефекти паперової основи документа;

2. Дефекти, зумовлені засобами фіксації друкованої інформації.

До дефектів паперової основи можна віднести такі:

- дефекти, спричинені деформацією паперу: видовження або ущільнення аркуша, викривлення або скручування;

- часткове або повне руйнування паперу, підвищена ламкість і крихкість;

- фізична втрата окремих частин аркуша паперу (через дію тварин та різних організмів: отвори на папері; обгризені краї паперу, корінці);

- склеювання листків (основна причина - це цвілеві гриби);

- механічні пошкодження: складки, розриви, сліди частих перегинів, проколи;

- пожовтіння паперу (внаслідок тривалого зберігання, залежить від властивостей і складу паперу);

- плями на папері (бруд; пігментні плями; плями, спричинені дією грибів, воску тощо);

• коричневий колір країв листків (обгорілі, підмочені та інші зовнішні фактори).

До дефектів, зумовлених засобами фіксації друкованої інформації, можна віднести такі: 
• вицвітання тексту - природне "чорнове" локальне або по всьому паперовому полю;

- втрата контрасту зображень і тексту;

- осипання друкованої інформації (внаслідок появи складок, розривів);

- поява розмазаних текстів внаслідок недотримання умов зберігання (підмочування сторінок, підвищеної вологості повітря в місцях зберігання архівів);

- порушення конфігурації окремих символів тощо.

Варто зазначити, що для візуального аналізу стародруку досить вибрати такі поодинокі показники якості:

1. Контраст між штрихами тексту і фоном зображення;

2. Повноту інформації, яка доступна на стародруці з дефектами;

3. Відсутність перешкод - плям, забруднень, поривів, проколів тощо.

3 погляду процесу реставрації як аналогу, так i оцифрованого стародруку, можна виділити такі види дефектів:

- слабкий контраст тексту за всім полем стародруку або локальний;

- нерівномірність фону на всьому полі стародруку або в локальних ділянках;

- напівпрозорі плями з постійною прозорістю;

- непрозорі плями, розриви;

- дрібні напівпрозорі плями у вигляді точок, подряпин;

- протяжні напівпрозорі плями - складки аркуша;

- протяжні непрозорі плями - розриви, подряпини;

- просвітлення написів на зворотному боці аркуша;

- шум у вигляді нерівномірних забруднень аркуша;

- зайва інформація (позначки, помарки тощо).

Наявність зазначених вище дефектів формує певний діапазон оптичних щільностей на оригіналі, що також потрібно враховувати як у процесі сканування, так і в цифровому обробленні для покращення характеристик цифрової копії. Для кожного з розглянутих видів дефектів розроблено свою процедуру їх усунення [9].

На етапі оцифровування документів на сьогодні електронні бібліотеки та архіви можуть обрати декілька основних напрямів кінцевого зберігання матеріалів залежно від їх наступного використання. У разі професійного використання рекомендують збереження копій у форматі TIFF (некомпресований) з роздільною здатністю від 600 ppi (pixels per inch), для користувацької копії - у форматі JPEG з роздільною здатністю 300 ppi, для оглядової (ознайомчої) копії - у форматі PDF (150 ppi), що передбачає також розміщення іiї в інтернет-ресурсах [6, 14].

Хоча існує ще третій варіант створення цифрових архівів стародруків, пов'язаний із їхньою інтерпретацією та мультимедійним супроводом. 3 розвитком мультимедійних технологій цей варіант набуває дедалі більшої популярності і проявляється у вигляді мультимедійного доповнення документа аудіо, відео контентом чи просторовими 3D-об'єктами. Наприклад, для старовинних документів 3 нотами передбачається можливість не тільки їхнього оцифровування, але й опрацювання $з$ додаванням автентичності звучання, як на той час, з використанням відповідних інструментів і особливостей виконання. Така інформація міститься в додатку до електронного видання, при цьому розробляється відповідний інтерфейс з інтерактивними можливостями для користувача у будь-який час прослухати аудіо-інформацію, чи передивитись реконструкцію відео. Моделювання 3D-об'єктів дає змогу заглибитись у віртуальну реальність тих часів, особливо це актуально в процесі навчання та пізнання, за якого залучаються майже усі людські рецептори сприйняття інформації під час використання новітніх технологій доповненої реальності. Цей напрямок тільки починає розвиватися і вже є вітчизняні напрацювання [2].

Для перетворення стародруків та рідкісних видань в електронний вигляд використовують спеціалізовані сканери. Вони дають змогу спростити завдання сканування і підвищити якість отриманих копій. Головною особливістю книжкового сканера $є \mathrm{~V}$-подібний тримач 3 притискним склом [3, 13]. Сторінки книги притискають склом, що дає змогу уникнути спотворень на зображеннях сторінок. Технологія оцифровування таких видань, особливо стародруків, є надто затратною і передусім через високу вартість апаратури, яка може вартувати кілька десятків, а то і сотні тисяч доларів. На ринку таке обладнання презентують такі компанії: Zeutschel GmbH, DIY Book Scanner, Image Access GmbH, Atiz Innovation Co., Ltd, Webgenic Technology Solutions, TREVENTUS Mechatronics GmbH, SMA Electronic Document GmbH, 4DigitalBooks - ASSY SA, i2S SA. Кожен з виробників пропонує декілька видів пристроїв для сканування стародруків, які відрізняться форматом, принципом розміщення книг, роздільною здатністю цифрових камер та різними інноваційними підходами. При цьому особливу увагу приділяють системам освітлення як у рівномірності розподілу по поверхні стародруку, так і в самій характеристиці джерел світла. Сучасні джерела світла для сканувального обладнання - це LED-випромінювачі з кольоровою температурою 6000 К, що унеможливлює зміну кольорових характеристик оригіналу небезпечними спектральними випромінюваннями.

Для виконання технологічних операцій із цифровими зображеннями стародруків використовують такі програми: ACDSee, Book Restorer, Page Improver, Scan Kromsator, Scan Tailor, і навіть Adobe Photoshop. Маючи набір таких програмних продуктів, можна створювати файли будь-якого графічного формату та з різними характеристиками.

На етапі сканування стародруків потрібно дотримуватись певних процедур, пов'язаних не тільки із забезпеченням цілісності оригіналів, але й виставленням необхідних параметрів та налаштувань процесу сканування. При виборі роздільної здатності сканування варто виставляти оптичну роздільну здатність сканера, яка забезпечує передачу інформації про оригінал в "реальних пікселях". На практиці це зазвичай 1200 пікселів на дюйм для планшетних сканерів і до 6400 - для професійних сканерів.

Робота будь-якої реєструвальної системи характеризується цифровим шумом. Цифровий шум - дефект зображення, який полягає у виникненні статистично неминучих хаотично розкиданих пікселів випадкового кольору і яскравості по площині зареєстрованого зображення, що відсутні в оригіналі. Зрозуміло, що величина цифрового шуму змінюється залежно від стану оригіналу, параметрів сканувального пристрою, принципів оброблення зображення програмним забезпеченням.

Алгоритм пошуку і подолання дефектів у вигляді перегинів на зображеннях стародруків розглянуто у працях [7, 12]. Дослідження й аналіз текстових документів 3 фонду рукописів і стародруків показали, що відносна частота появи дефекту у вигляді перегинів становить 0,07. Тобто з 20 виділених на текстових документах дефектів, відповідно до класифікації, дефект у 
вигляді перегинів знаходиться на сьомому місці за частотою [9]. Отже, актуальною $є$ задача автоматичного пошуку і видалення такого типу дефектів.

Перегини характеризуються областю визначення протяжного за напрямком дефекту на дискретному зображенні, по дискретному аналогу математичної лінії на неперервній площині. Тому їх можна характеризувати в такий спосіб:

- за напрямком згину: випуклі та вгнуті;

- за протяжністю: які поширюються на все зображення, або в деякій локальній області.

Найчастіше трапляються вертикальні і горизонтальні перегини, які проходять через все зображення і перегини кутів сторінок оригіналів. В алгоритмі виділення дефекту перегину використовуються операції математичної морфології [12], та узагальнені перетворення Хоха. Виявляється, що ділянки в області дефекту перегину освітлюються нерівномірно променем сканера, через різні кути нахилу тих суміжних ділянок відносно площини розміщення оригіналу. Отже, перегин можна вважати складником із двох частин - світлої і темної. Тому алгоритм виділення дефекту перегину містить етапи: послідовне виділення світлих та темних протяжних ділянок дефекту - відбувається шляхом бінаризації зображення півтоновим морфологічним розмиканням; об'єднання темних і світлих ділянок дефекту і областей між ними за умови їх паралельного і близького розміщення. При цьому виключається виділення лінійних об'єктів, що не належать до перегинів.

Після визначення дефекту перегину і підтвердження оператором відбувається видалення методом граничної сегментації елементів зображення, які належать до перегину. Відома розробка автоматизованої системи цифрової реставрації стародруків, яка базується на бінаризації зображень 3 наступним їх суміщенням [7].

Розроблено спосіб компенсації відсутності елементів зображення на сторінках стародруків під час їх оцифровування [17]. За методу компенсування відсутності елементів під сторінкою розміщують відмінну від оригіналу вставку (білу або кольорову), фон якої буде орієнтиром для автоматизованого сегментарного заповнення відсутньої ділянки вибраним елементом зображення стародруку згідно з математичною моделлю. Перевагою такого способу є автоматизація операції заповнення пошкодженої (відсутньої) ділянки сторінки стародруку вибраними однотипними елементами зображення.

Після оцифрування, оригінальний документ залишається у сховищі і всі наступні операції виконуються 3 цифровою копією. Цифрова реставрація дає змогу змінювати й обробляти цифрові копії оригінальних документів і з орієнтацією на різні застосування, що дає змогу забезпечити доступ до зафіксованої на них інформації як без візуальної зміни початкового цифрового документу, так і з поліпшенням характеристик яскравості і геометричної корекції, виділенням і виправленням дефектів, перетворенням документа у форму електронної книги, формування комбінованого подання документа у формі "текст" + "зображення тексту", що поєднує достовірне графічне подання вихідного документа з кодованим текстом для копіювання, індексування, пошуку інформації тощо.

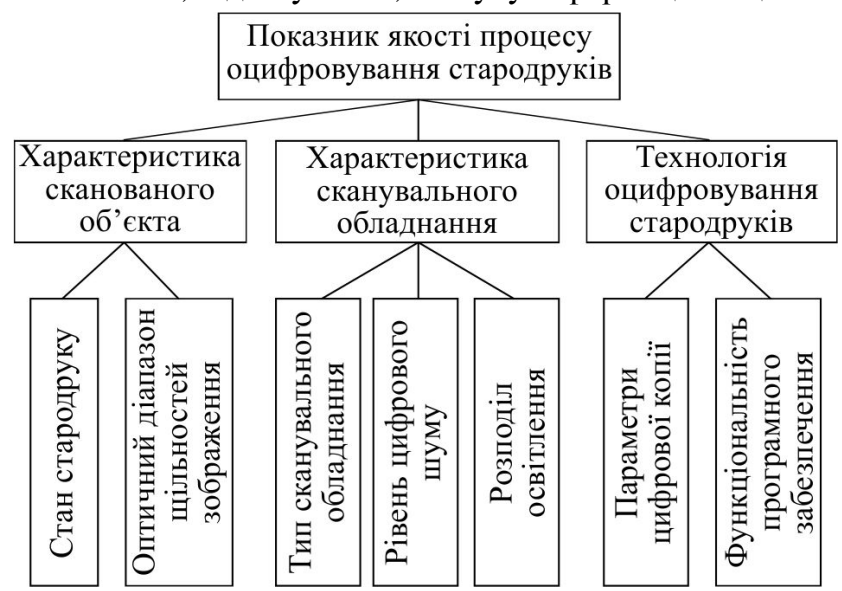

Рис. 1. Графічна модель формування показника якості основними факторами процесу оцифровування стародруку

3 виконаного вище аналізу можна виокремити основні фактори, врахування особливостей яких уможливлює забезпечення якості процесу оцифровування стародруків: стан стародруку, оптичний діапазон щільностей зображення на сторінці стародруку, особливість сканувального обладнання, розподіл освітлення під час оцифровування, функціональність програмного забезпечення, рівень цифрового шуму, характеристика цифрової копії. На рис. 1 показано модель формування якості основними фактограмами процесу оцифровування стародруків, у якій зазначені фактори згруповані за характеристикою сканованого об'єкта, характеристикою сканувального обладнання і технологією оцифро-

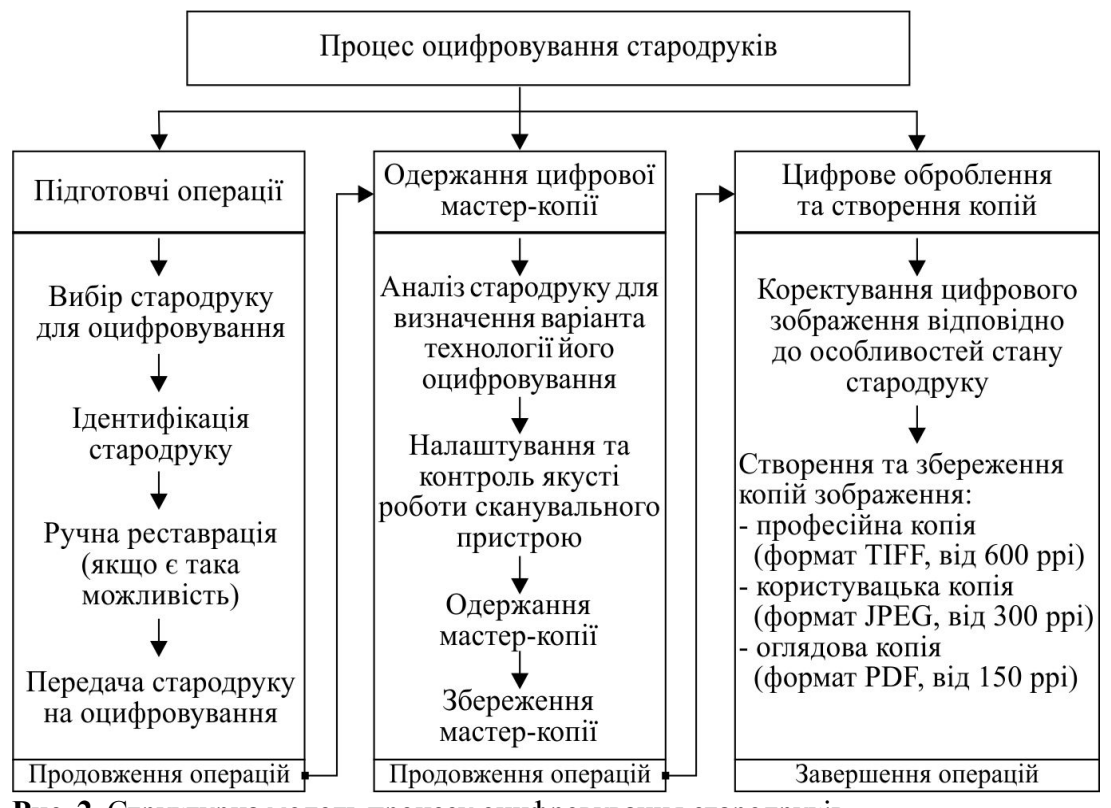
модель процесу оцифровування стародруків вування стародруків.

Відповідно, за результатами здійсненого аналізу, розроблено узагальнену структурну модель процесу оцифровування стародруків (рис. 2), яка містить підготовчі операції, що передують оцифровуванню стародруку, операцію отримання цифрової мастер-копії і цифрове оброблення копій, залежно від мети застосування, зокрема оброблення для видавничо-поліграфічного відтворення. 3 рис. 2 видно, що для зберігання на різних носіях і для різних потреб використовують різні пара- 
метри якості, що насамперед залежать від роздільної здатності отриманого зображення. Процес оцифровування умовно розбито на три функціональні блоки, кожен із яких вносить свої корективи на комплексний параметр якості. Отже, для того, щоб визначити найбільш оптимальні параметри опрацювання цифрових копій стародруків, необхідно зосередитись на кожній технологічній операції підготовчого процесу, отримання цифрових майстер-копій та оброблення і створення копій різного призначення.

\section{Висновки}

Виконаний аналіз технологічного процесу оцифровування стародруків дав змогу згрупувати дефекти, які $\epsilon$ характерними для видань, що обробляються, так і дефекти, отримані на цифрових копіях. Встановлено, що залежно від використання цифрового документа, він зберігається у різних форматах і з різною роздільною здатністю. Відповідно, розроблено структурну модель процесу оцифровування стародруків, яка містить підготовчі операції, що передують оцифровуванню стародруку, операцію отримання цифрової мастер-копії і цифрове оброблення копій, залежно від мети застосування, зокрема оброблення для видавничо-поліграфічного відтворення. Встановлено основні фактори, які визначають якість процесу оцифровування стародруків, що уможливить їх дослідження методами теорії ієрархій та побудову моделі прогнозування якості оцифровування засобами нечіткої логіки.

\section{References}

1. Barkova, O. V. (2019). Otsyfrovani dzherela z istorii osvity: vymohy ta pidkhody do tsyfrovoi reprezentatsii knyzhkovykh pamiatok v onlainovykh resursakh. Retrieved from: http://lib.iitta.gov.ua/717857/1/Barkova_Otsyfrovani.pdf. [In Ukrainian].

2. Barkova, O., Ostapova, I., \& Mordvynov, Yu. (2005). Prezentatsiia rukopysiv i starodrukiv u tsyfrovomu seredovyshchi. Bibliotechna planeta, 1, 20-24. Retrieved from: http://nbuv.gov.ua/ UJRN/ bp_2005_1_8. [In Ukrainian].

3. BookDrive DIY. (2020). Retrieved from: https://www.atiz.com/ atiz_connect/bookdrive_diy/brochures/brochure_diy.pdf.

4. Global Document Imaging Market-Industry Analysis and Forecast (2020-2027). (2020). Maximize Market Research PVT. LTD. Retrieved from: https://www.maximizemarketresearch.com/market-report/global-document-imaging-market/55258/.
5. Guidelines for Planning the Digitization of Rare Book and Manuscript Collections. (2014). Written by the IFLA Rare Book and Special Collections Section, September, 1-19.

6. Iurchenko, O. A. (2019). Reshenie problem otcifrovki bibliotechnogo fonda: opyt Nauchnoi biblioteki Dalnevostochnogo federalnogo universiteta. Nauchnye i tekhnicheskie biblioteki, 1, 5462. [In Russian].

7. Iuzhikov, V. S. (2006). Avtomatizirovannaia sistema restavratcii i obrabotki izobrazhenii staropechatnykh tekstov i rukopisei. Retrieved from: https://elbib.ru/article/view/285/308. [In Russian].

8. Kanunova, E. E., \& Naumova, F. Iu. (2017). Obzor metodov tcifrovoi obrabotki izobrazhenii dlia tcelei vydeleniia $i$ ustraneniia defektov na arkhivnykh dokumentakh. Retrieved from: http://amisod-2017-02-36-kanunona-naumova.pdf. [In Russian].

9. Kanunova, E. E., \& Poliakova, E. V. (2008). Algoritm poiska $i$ ustraneniia defektov $v$ vide peregibov na izobrazheniiakh tekstovykh dokumentov. Retrieved from: http://elibrary_15618818 985597543.pdf. [In Russian].

10. Kovalchuk, H. (2008). Stvorennia elektronnykh informatsiinykh resursiv knyzhkovykh pamiatok v NBUV. Bibliotechnyi visnyk, 3, 3-10. [In Ukrainian].

11. Lande, D., \& Barkova, O. (2013). Elektronna biblioteka yak seredovyshche adaptyvnoho ahrehatuvannia informatsii. Bibliotechnyi visnyk, 2, 12-17. [In Ukrainian].

12. Maragos, P., \& Shafer, R. (1990). Morfologicheskie sistemy dlia mnogomernoi obrabotki signalov. Trudy instituta inzhenerov po elektronike i radiotekhnike, 45-50. [In Russian].

13. Ovsak, O. S. (2008). Praktychnyi dosvid vykorystannia suchasnoho skanuiuchoho obladnannia dlia otsyfruvannia knyzhkovykh fondiv bibiliotek. Retrieved from: http://journals.dnpb.gov.ua/article/ view/72252/74211. [In Ukrainian].

14. Rekomendatcii po otcifrovke materialov iz fondov bibliotek. (2013). Ekspertnyi sovet po tcifrovym kopiiam. Elektronnye tekstovye dannye. Retrieved from: http://www.nlr.ru/pro/inv/digit_copy/recom.pdf. [In Russian].

15. Sadykov, S. S. (2007). Kompiuternaia restavratciia arkhivnykh tekstovykh dokumentov. Otechestvennye arkhivy, 1. Retrieved from: https://www.elibrary.ru/download/elibrary_9290097_6134 8397.pdf. [In Russian].

16. Starovoitov, V. V. (2015). O tcifrovoi restavratcii istoricheskikh dokumentov. Sistemnyi analiz i prikladnaia inofrmatika, 1, 60-66. [In Russian].

17. Tsimer, O. B., Repeta, V. B., \& Myklushka, I. Z. (2020). Sposib kompensuvannia vidsutnosti elementiv zobrazhennia na starodrukakh pry yikh otsyfrovuvanni. Pat. na kor. mod. u201909958 Ukraina. B41B 13/00. [In Ukrainian].

18. Vlashchenko, L. H., \& Hryshchenko, T. B. (2005) Tekhnolohiia stvorennia kolektsii povnotekstovykh elektronnykh vydan u bibliotekakh. Bibliotechnyi forum Ukrainy, 4, 26-30. [In Ukrainian].

\section{O. B. Havrylyshyn, V. B. Repeta, I. Z. Myklushka}

Ukrainian Academy of Printing, Lviv, Ukraine

\section{THE ANALYSIS OF THE PROCESS OF OLD BOOKS DIGITALIZATION}

The paper analyses the features of the digitization process of old printed editions as one of the modern methods of preserving Ukrainian and world cultural heritage. In the course of the study main shortcomings and defects of the paper base of old books and the image applied to it are established, their impact on the parameters of the received digital copy and options for their solution, both at the level of specialized equipment and at the level of software have been identified as well. The stages of transformation of old printed editions into electronic form and options for saving a digital copy depending on the purpose have been considered. The authors have classified the main factors, which features allow ensuring the quality of the digitization process of old books and building a model for prognostic evaluation. These factors are as follows: the condition of an old book; the optical range of the image on the old book page; the type of scanning equipment; light distribution when digitizing, software functionality; the level of digital noise; digital copy characteristics. Some features of the scanning equipment for old book editions have been defined to be as follows: the presence of V-shaped holder to prevent the destruction of the scanned rare book; the resolution of the system not less than 600 ppi, which allows high-quality printing if necessary; colour temperature of the light source of $6000 \mathrm{~K}$ to prevent colour distortion of the original during its digitization and to provide an appropriate range of optical density. Thus, a structural model of the digitization process of old books has been developed based on the analysis, which includes preparatory operations preceding the digitization of old books, the operation of receiving a digital master copy and digital processing of copies depending on the purpose of application, in particular, processing for publishing and printing reproduction.

Keywords: old book; digitization process; defects of original; quality factors; saving formats; structural model. 